\title{
UC Desert Research and Extension Center celebrates 100 years
}

W hen the UC Desert Research and Extension Center (UC DREC) was established in the Imperial Valley in 1912, water from the Colorado River was so available that dairies were plentiful in this desert region, along with feedlots for steers born to milk cows and fields of alfalfa to feed all those cattle.

While most of the dairies are long gone and the water supply has been tightened to meet urban demands on the Colorado River, the Imperial Valley's cattle feedlots and field crops have grown. In addition farmers there have expanded into high-value crops such as winter vegetables and melons.

"The Imperial Valley is one of the largest agricultural areas in California," says Bill Frost, director of UC Agriculture and Natural Resources (ANR) Research and Extension Center (REC) system, which has nine centers spanning the state to support research tailored to local needs. "DREC is right in the middle of the desert, enabling the University to focus on locally relevant critical issues."

\section{Agriculture in the Imperial Valley}

Initially called the Meloland Field Station and later the Imperial Valley Field Station, UC DREC was the first addition to what became the ANR REC system. The 255-acre center is in the middle of an agricultural region called the low desert that encompasses

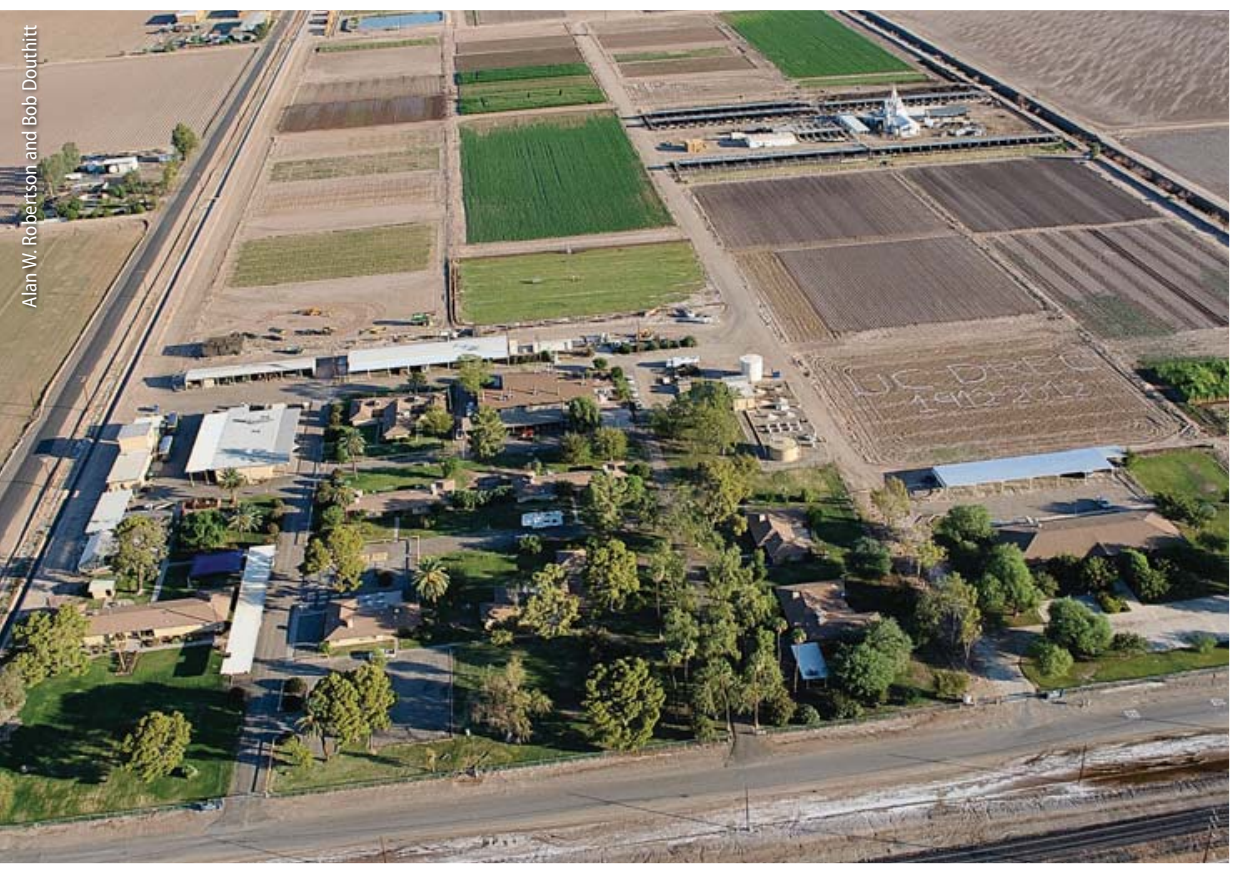

The UC Desert Research and Extension Center is located in the heart of the Imperial Valley in southeastern California, on 255 acres. The area was formerly Colorado River floodplain, so its soils are deep and rich, but there is very little rainfall. Farming in this desert environment presents unique challenges.

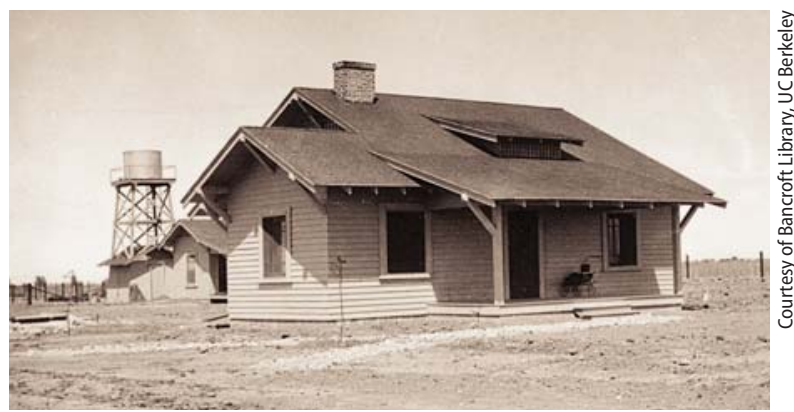

Walter Eugene Packard established UC's Meloland Field Station in the Imperial Valley in 1912 and served as superintendent until 1917. He lived in this house.

California's Imperial and Coachella valleys, Arizona's Yuma Valley and Mexico's Mexicali Valley.

As a former Colorado River floodplain, the Imperial Valley has deep, rich soil. But rainfall averages less than 3 inches per year and summer temperatures can reach $120^{\circ} \mathrm{F}$.

The winters, however, are sunny and mild, with highs in the $80 \mathrm{~s}^{\circ} \mathrm{F}$, allowing the year-round production that has helped make Imperial a top-10 agricultural county in California. The county had nearly $\$ 2$ billion in gross agricultural production in 2011, and its top commodity groups are livestock, valued at more than $\$ 400$ million; field crops, including alfalfa, wheat and sudangrass, at nearly $\$ 520$ million; and melons and vegetables, including lettuce, broccoli and onions, at more than $\$ 900$ million. About two-thirds of the vegetables eaten nationwide during winter are grown in Imperial County.

"We have perfect weather for winter vegetables. It's not too hot and hardly rains, so you can harvest all the time - the weather never gets in the way," says UC DREC superintendent Fernando Miramontes, who started there 33 years ago as a part-time field-worker and now oversees all research projects.

\section{UC DREC research contributions}

DREC's research facilities include greenhouses, a plant- and soil-processing laboratory, an insectrearing facility, a fully automated sprinkler area and a research feedlot cattle facility. The center has an annual operating budget of about $\$ 800,000$ and research operations budget of over $\$ 500,000$; with the help of more than a dozen administrative and field research support staff, scientists from UC as well as the USDA Agricultural Research Station in Salinas, more than 25 research projects are currently under way.

Over the past century of changes, UC DREC researchers have helped Imperial Valley farmers meet the many challenges of desert agriculture, including lack of water, extreme summer heat, and rampant pest 
insects that devour crops and spread diseases. The center's major contributions (see timeline) include:

- Developing cattle feeds and shade structures to enhance feedlot production during the summer, when high temperatures hinder livestock weight gain.

- Developing plastic-tile drainage systems to maintain soil productivity by flushing salt from the root zone.

- Increasing the yields and pest resistance of desertgrown crops, from alfalfa and wheat to melons and lettuce.

- Testing thousands of rice lines from around the world for introduction to California.

In addition, today's UC DREC researchers are helping farmers prepare for the future by, for example, exploring the potential of sugar cane and other crops for biofuel feedstocks and by creating crop varieties that are adapted to climate change.

\section{Feedlot cattle nutrition, care and production}

UC DREC is a national leader in feedlot cattle research, with one of the largest university facilities, including a 700-head feedlot, more than 100 pens, a metabolism barn and a feedmill. Led by Richard Zinn, a UC Davis professor of animal science, the research focuses on optimizing feedlot cattle health and management in the extreme heat of the low desert summers.

In addition to helping cattle producers in the Imperial Valley, Zinn and colleagues collaborate with researchers at the Universidad Autonoma de Baja California (UABC), in Mexicali, Mexico, which is just over the border from UC DREC. Beginning with short courses in animal science at the UABC in 1984, this collaboration has grown to include Masters and $\mathrm{PhD}$ animal production programs there. Such programs offer students UABC faculty advisors coupled with research training and thesis work in UC DREC's comprehensive feedlot facilities. The collaboration has also led to UC DREC's participation in developing

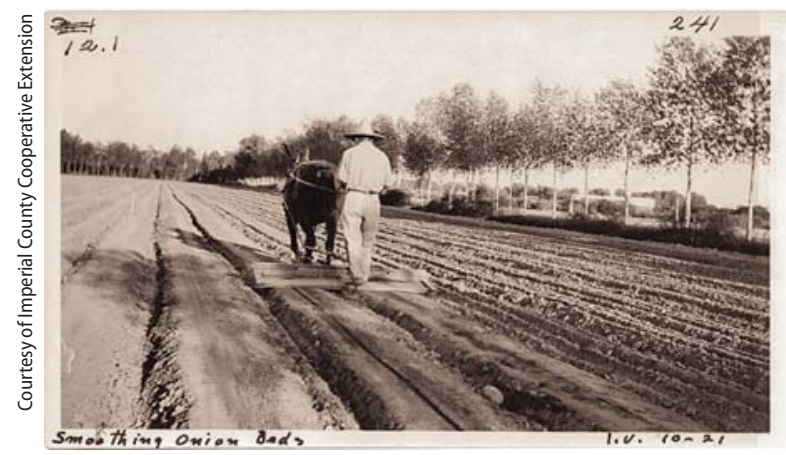

In October 1921, an Imperial Valley farmer and his mule created beds for onion seeding.

\section{Desert Research and Extension Center timeline}

1912

UC establishes Meloland Field Station on 10 acres near El Centro.

1945 UC expands the station, by then called the Imperial Valley Field Station, to 255 acres.

1948 Results of first research on artificial shades for livestock published by N.R. Ittner and C.F. Kelly; research by V.E. Mendel, W.N. Garrett and others follows.

1940 s \& Research to develop plastic-tile drainage led by James Luthin.

$1950 \mathrm{~s}$

1960s \& Research to develop blue alfalfa aphid-resistant alfalfa led by

1970s William Lehman.

1962 Research milestones published, including development of 'Calmar' lettuce, which resists downy mildew, and the 'M-100' onion, which resists bolting in the heat.

1967 First sprinkler irrigation results published by F.E. Robinson, O.D. McCoy and G.F. Worker, Jr.

1970 Results of first rice lines tested for introduction to California published by W.F. Lehman, M.I. Peterson, C.R. Adair and others.

1973 'Signal' barley, a variety that has high yields in the low-elevation desert, released to growers.

1970s \& Research to develop 'CUF 101' alfalfa, which produces year-

1980s round in the low desert and is resistant to multiple pests, led by William Lehman.

1984 Richard Zinn and Juan Guerrero Cruz begin collaborating with the Universidad Autonoma de Baja California (UABC), in Mexicali, Mexico, leading to $U A B C$ Masters and $\mathrm{PhD}$ research in animal nutrition and production at UC DREC.

1990s Whitefly-resistant alfalfa developed by Larry Teuber.

2001 Farm Smart agricultural education program established.

2006 Biofuel crop trials begun by Dan Putnam and David Grantz.

2012 Heat-tolerant lettuce and spinach trials begun by Beiquan Mou. October 25, 2012, Center celebrates 100th anniversary.

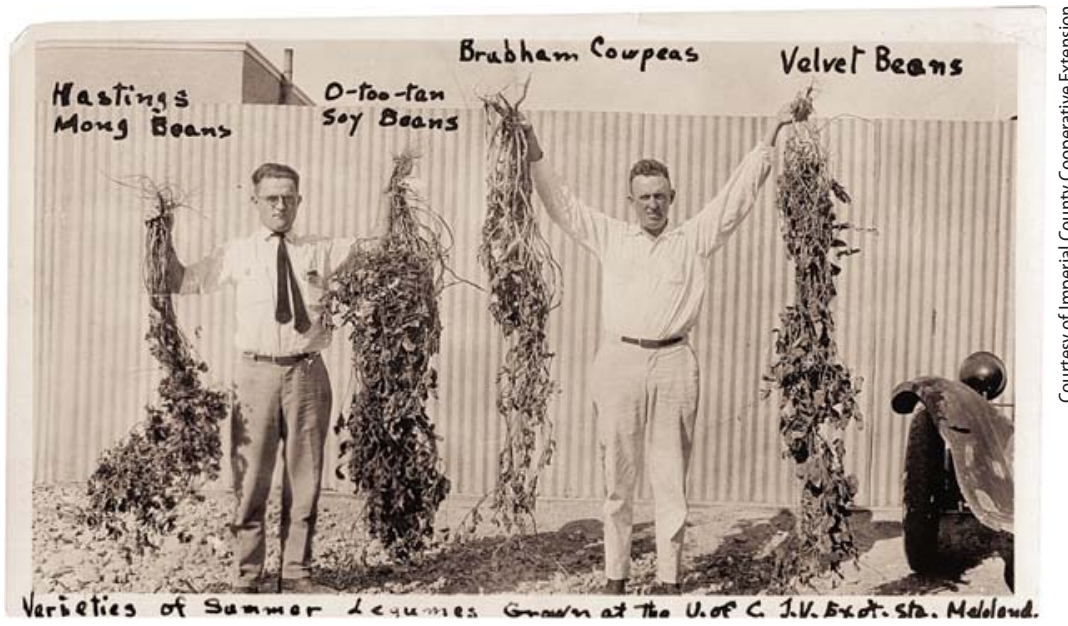

Throughout the 1920s and 1930s, the Imperial Valley Experiment Farm was staffed by one agronomist/superintendent. This picture of summer legumes was taken in 1924. 


\section{Farm Smart offers hands-on experience, insight into where food comes from}

$\mathrm{O}$ ne of the highlights of UC DREC is an agricultural education program called Farm Smart, which was developed by former elementary school teacher Nancy Caywood. Also a farmer's

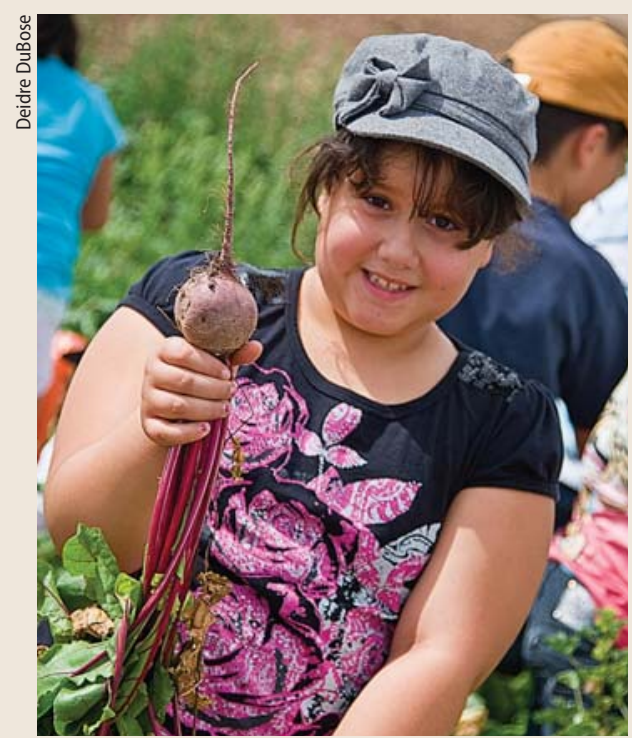

About 8,000 K-12 students visit DREC each year as part of the Farm Smart program. Activities include harvesting and sampling vegetables.

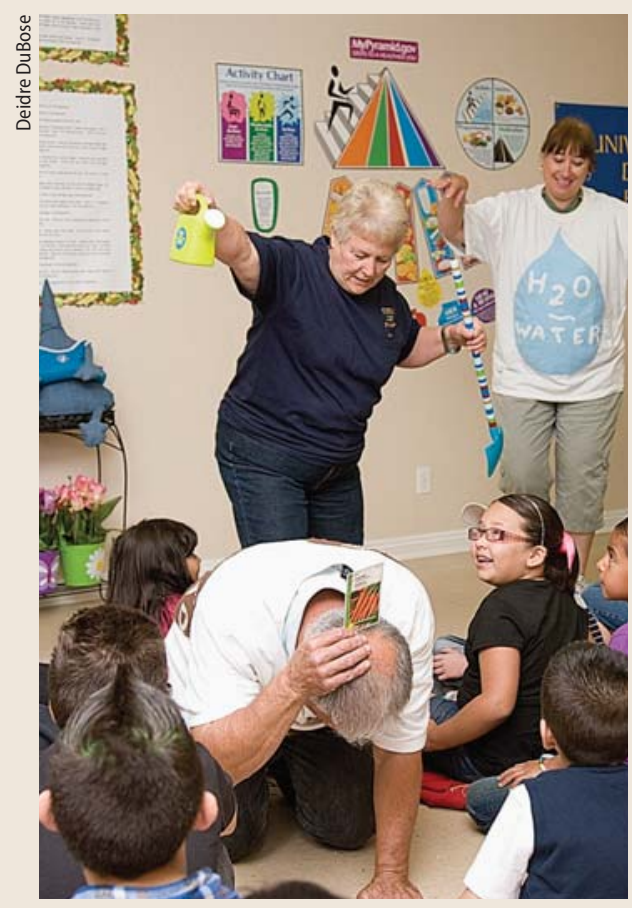

Participants learned about soil types by playing interactive games led by Farm Smart outreach coordinator Nancy Caywood (center). daughter, Caywood got into agricultural literacy when she asked her 1st- and 2ndgrade students where food came from. "They said 'from the grocery store' and that really bothered me," Caywood recalls. "So I asked if I could bring my kids to the farm." The resulting field trips prepared Caywood for her next career as the Farm Smart outreach coordinator at UC DREC.

Established in 2001, Farm Smart provides K-12 agricultural outreach and education programs for just $\$ 3$ per student. Funding also includes $\$ 50,000$ annually from the Imperial Irrigation District as well as support from the Imperial County Farm Bureau and local seed companies. "The community makes this happen," Caywood says.

With a team of volunteers that includes her husband, Alan Robertson, Caywood offers more than 150 daylong agricultural education programs to nearly 8,000 students each year. The curriculum is aligned with the content standards for California public schools, covering topics including health and nutrition, bees and pollination, and natural and renewable natural resources. Designed to be fun as well as informative, the programs emphasize hands-on activities, from harvesting and eating winter crops to milking artificial cows and making butter, and also include hayrides and sing-alongs.

During January and February, Caywood offers a similar outreach

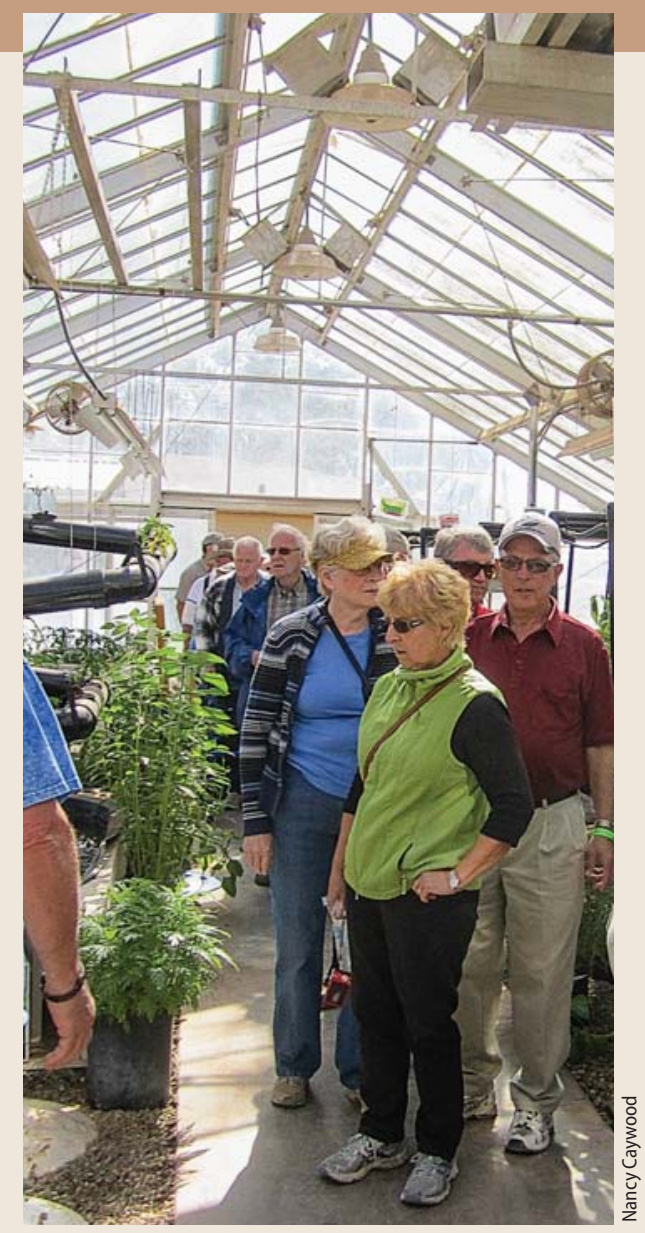

During the winter, adults visit DREC to learn about natural and renewable resources in the Imperial Valley, including agriculture.

program to the "snowbirds," retirees who flock from cold climates to the Imperial Valley. Called the Winter Visitor program, this Farm Smart component enrolls about 3,000 participants.

"Most people just don't know much about agriculture," Caywood says.

"We help them learn where their food comes from." _ Robin Meadows

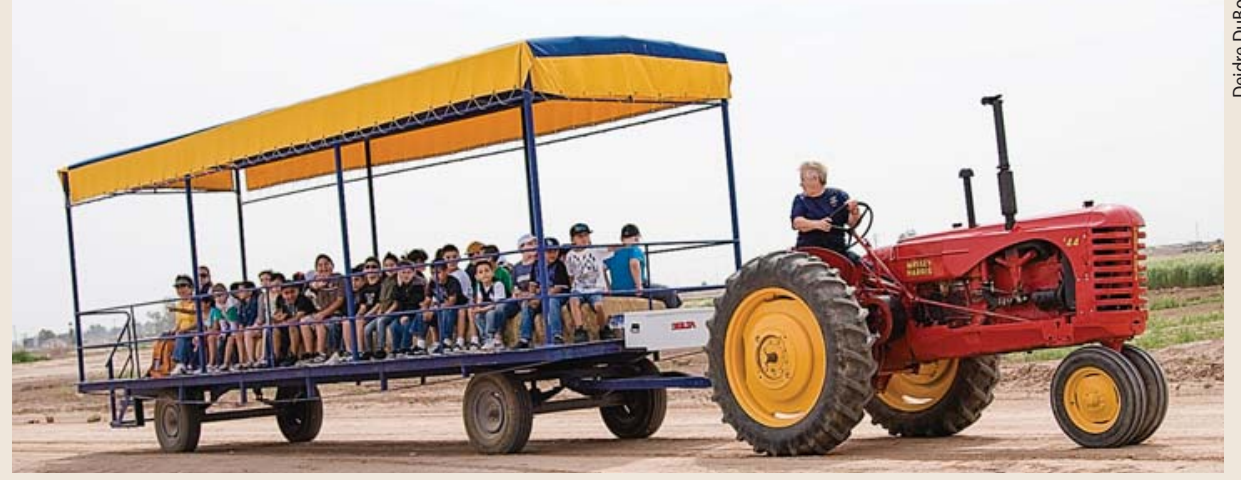

During Fall Fest in November and December, students go on hayrides, grind corn and dance to traditional music. Other seasonal activities include ice-cream making in October, the USDA food pyramid in March and April, and insects in May; all students learn about irrigation and water. 
and strengthening postgraduate animal science programs at several other Mexican universities.

\section{Water conservation and quality}

Because rain is so scarce, the Imperial Valley depends entirely on the Colorado River for irrigation water. While this water flowed freely for decades, today growers must contend with competing demands from Southern California cities.

"Water transfers between agricultural and urban areas put increased pressure on growers to conserve to meet the needs of the future," says Khaled Bali, UC DREC interim director and UC Cooperative Extension Imperial County irrigation/water management advisor. So far, transfer agreements have claimed about one-tenth the water once used for irrigation in the Imperial Valley.

The bulk of the irrigation water goes to field crops, which account for $80 \%$ of the 500,000 cultivated acres in Imperial County; most of the crops are primarily flood irrigated. UC DREC water conservation projects include lining irrigation canals, automating flood irrigation and developing strategies for using less water during the summer. "We are working to match water with crop needs," says Bali, who has worked at UC DREC for more than 20 years.

However, water conservation is complicated by local environmental factors. "One of the biggest issues is salinity," Bali says. "It's so hot that lots of the irrigation water evaporates, adding 7 tons of salt per acre per year." Most crops, particularly vegetables, are salt sensitive. But getting rid of salt means flushing the soil with even more water. "We're working to decrease runoff and optimize deep percolation, so there will be enough water to flush salts but not so much that there's waste," Bali says.

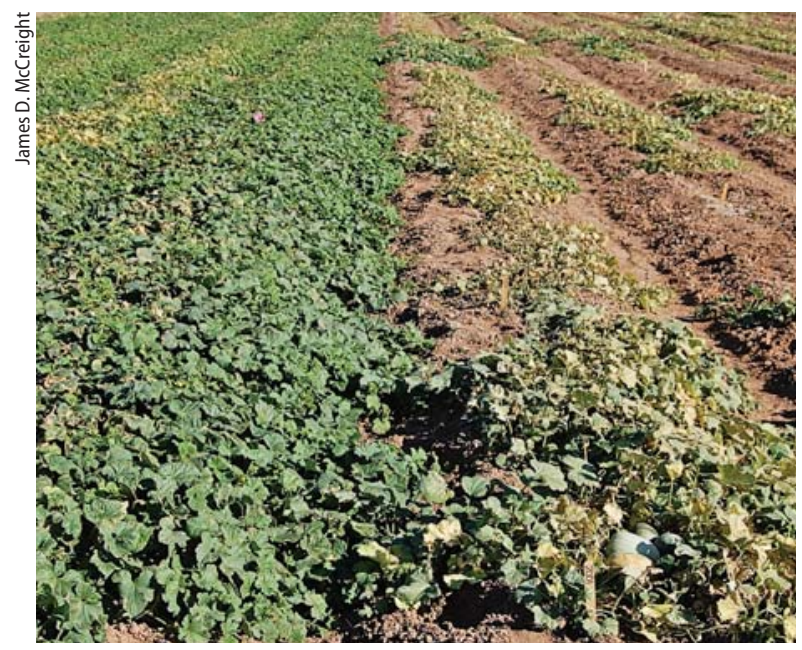

In field research at DREC conducted by USDA researchers, the melons from India on left show genetic resistence to cucurbit yellow stunting disorder virus; melons susceptible to the disease are on right.

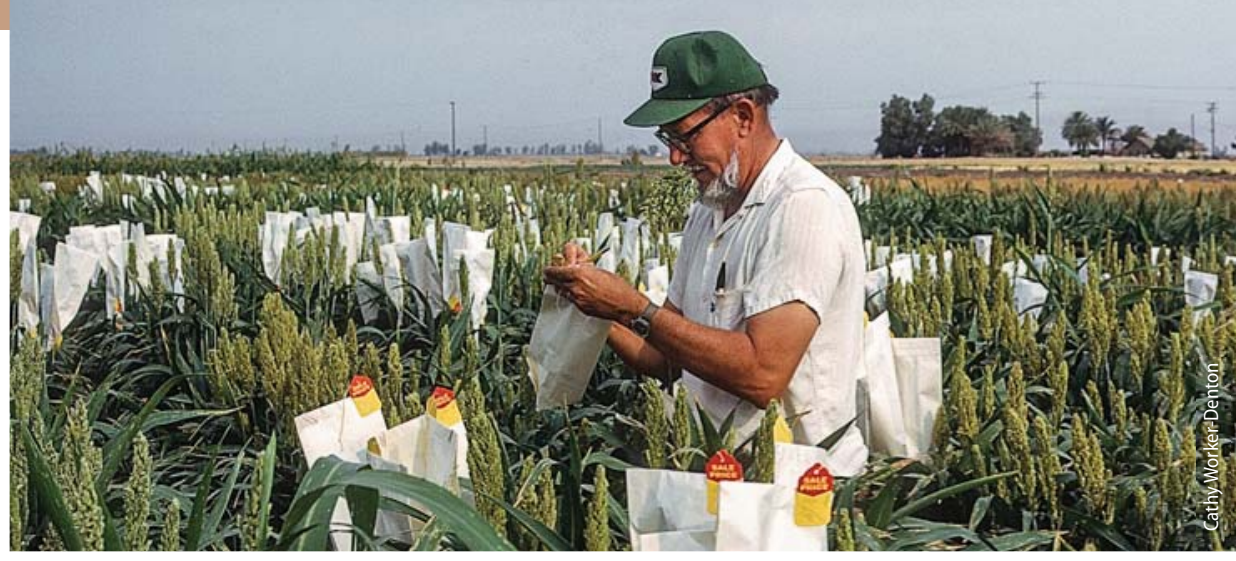

UC agronomist George F. Worker served at DREC from 1953 to 1985 . In the early 1980s, he pollinated sorghum for field trials.

Another difficulty is that agricultural wastewater is critical to the Salton Sea, which provides important bird habitat. "The Imperial Valley drains naturally into the Salton Sea, so more water conservation means less water for the Sea," Bali says. The influx of relatively fresh agricultural water is needed to counterbalance the salt-concentrating effects of evaporation, and the Salton Sea is already about 30\% saltier than the ocean.

\section{Low desert alfalfa}

Alfalfa is the Imperial Valley's biggest water user, consuming more than a third of the available irrigation water. It is also the region's most extensive and valuable field crop, with nearly 120,000 acres in production and valued at $\$ 120$ million in 2011. "Alfalfa has been important in the Imperial Valley from the very beginning," says Dan Putnam, a UCCE agronomist and forage specialist based at UC Davis. "There were thousands of small dairies in the early 1900s, and most grew alfalfa." Today, most of the region's alfalfa is shipped to dairies in Chino, San Bernardino County, which is among the state's largest milk-producing areas.

One of UC DREC's most important contributions is a variety of alfalfa developed in the 1970s by agronomist William Lehman. Called CUF 101, this alfalfa variety resists the blue alfalfa aphid and grows through the winter in the low desert rather than going dormant. "This saved the alfalfa industry because the aphid was decimating the crop in California," Putnam says. "CUF 101 also increased yields, revolutionizing alfalfa production in California as well as in Argentina, Australia, South Africa and the Middle East."

Putnam, who has worked on alfalfa for more than 20 years, tests varieties statewide to optimize local yields. "UC DREC is a terrific environment for testing for heat tolerance and long production seasons," he says. Thanks to winter growth in the Imperial Valley, today's alfalfa varieties produce up to 12 harvests per year, which is four times that in some parts of the state. 
